\title{
The U-Curve of E-Learning: Course Website and Online Video Use in Blended and Distance Learning
}

\author{
Nitza Geri \\ The Open \\ University of Israel, \\ Raanana, Israel
}

\author{
Ruti Gafni \\ The Academic \\ Amir Winer \\ The Open \\ College of Tel Aviv University of Israel, \\ Yaffo, Israel and \\ The Open \\ University of Israel, \\ Raanana, Israel \\ Raanana, Israel
}

\section{nitzage@openu.ac.il rutigafn@mta.ac.il amirwi@openu.ac.il \\ nitzage@openu.ac.il rutigafn@mta.ac.il amirwi@openu.ac.il}

\section{Abstract}

Procrastination is a common challenge for students. While course Websites and online video lectures enable studying anytime, anywhere, and expand learning opportunities, their availability may increase procrastination by making it easier for students to defer until tomorrow. This research used Google Analytics to examine temporal use patterns of course Websites, with an emphasis on online video lectures. We analyzed pageview data of 8,977 students enrolled in two compulsory undergraduate courses, one of which is offered exclusively fully online, and three elective courses, one for undergraduates, and two for master of business administration (MBA) students, over a period of two years. Our findings showed a significant u-curve of e-learning for all courses, during all the examined semesters, for courses' homepage views, as well as for their main video page. We evaluated the depth of the mid-semester decline in e-learning and generally found no significant differences among courses, or over time. However, the relative decline in access to the main video page of undergraduates enrolled in compulsory courses was significantly larger than that of undergraduate and MBA students in elective courses, thus, suggesting that procrastination of video views was slightly higher in compulsory courses. The implications of the findings are discussed.

Keywords: online video lectures, procrastination, effectiveness of instructional technologies, blended learning, distance learning, continued use of information systems, attention economy.

Material published as part of this publication, either on-line or in print, is copyrighted by the Informing Science Institute.

Permission to make digital or paper copy of part or all of these works for personal or classroom use is granted without fee provided that the copies are not made or distributed for profit or commercial advantage AND that copies 1) bear this notice in full and 2) give the full citation on the first page. It is permissible to abstract these works so long as credit is given. To copy in all other cases or to republish or to post on a server or to redistribute to lists requires specific permission and payment of a fee. Contact Publisher@InformingScience.org to request redistribution permission.

\section{Introduction}

Online technologies have greatly enhanced distance and blended learning over the last 20 years. However, perseverance is considered harder in elearning environments. The flexibility and availability of e-learning, particularly online video lectures, make it easier for students to procrastinate. While in 
informal e-learning courses, such as Massive Open Online Courses (MOOCS), procrastination may cause withdrawal, in formal e-learning contexts we would expect most students to have a ucurve e-learning pattern similar to that of the familiar traditional face-to-face learning cycle. At the beginning of the semester students may be enthusiastic or feel committed and allocate adequate attention resources to learning, during the middle their learning effort decreases, toward the end it increases, and just prior to the exam they exert the greatest efforts to study the course content.

Online video lectures are sometimes perceived as substitutes for face-to-face class meetings (Copley, 2007). There is a growing trend of online video lecture use in distance learning, blended learning, traditional face-to-face learning that migrates to blended models, MOOCS, and diverse sorts of life-long learning. Thus, it is important to study the temporal use patterns (Grinberg, Naaman, Shaw, \& Lotan, 2013) of online video lectures and analyze their implications for procrastination and e-learning processes.

The purpose of this study is to examine temporal use patterns of course Websites and focus on the use of online video lectures on their own, as well as relative to general use patterns of course Websites, as expressed in pageviews of their homepage.

The majority of prior studies of procrastination in learning (e.g., Ackerman \& Gross, 2005; Cao, 2012; Kachgal, Hansen, \& Nutter, 2001; Özer, Demir, \& Ferrari, 2009; Wang, He, \& Li, 2013), and online learning (e.g., Michinov, Brunot, Le Bohec, Juhel, \& Delaval, 2011; Rakes \& Dunn, 2010) were based on surveys, in which students self-reported their perceptions. Some studies, such as Ariely and Wertenbroch (2002), used experiments. However, just a few studies that investigated procrastination in learning (e.g., Levy \& Ramim, 2012) were based on objective data of student behavior (Hershkovitz \& Nachmias, 2009) or utilized data analytics (LaValle, Lesser, Shockley, Hopkins, \& Kruschwitz, 2011).

This study used Google Analytics (Clifton, 2012) to examine e-learning temporal patterns (Grinberg et al., 2013) of a sample that included 8,977 students who were enrolled in selected five courses during the years 2012 and 2013. Diverse types of courses were included in the sample in order to explore other factors that may affect e-learning and online video lecture temporal use patterns, as well as increase the generalizability of the findings. The sample included compulsory and elective courses, fully online and blended courses, as well as undergraduate and master of business administration (MBA) ones, and various topics: finance, information systems analysis, political science, project management, and strategy. All courses have been offering online video lectures for at least two years prior to the investigated period. Hence, this study examined continued use (Bhattacherjee, 2001; Geri, \& Naor-Elaiza, 2008) patterns rather than adoption of online video lectures.

We used an interdisciplinary theoretical background, which included procrastination literature (Steel, 2007), cognitive fit theory (Adipat, Zhang, \& Zhou, 2011; Vessey, 1991), attention economy (Davenport \& Beck, 2001; Geri \& Geri, 2011; Shapiro \& Varian, 1999), distance learning (Moore \& Kearsley, 2011), informing science (Cohen, 1999, 2009), and more, to develop hypotheses regarding the following research questions:

- What are the general temporal use patterns of course Websites?

- What are the temporal use patterns of online video lectures?

- Does the temporal use pattern of online video lectures differ from the general temporal use pattern of a course Website? 
- Do fully online courses have temporal use patterns of video that are different than those of blended courses? Are there differences in online video lecture use for exam preparation?

- Are there differences in procrastination between undergraduates and postgraduates, as observed in e-learning temporal use patterns?

- Is there more procrastination, as observed in e-learning temporal use patterns, in compulsory courses than in elective ones?

- Are there differences over time in the temporal e-learning patterns, which may imply changes in procrastination?

The most important finding of our study is the significant u-curve of e-learning, which was found in all courses. To the best of our knowledge there are hardly any similar empirical reports that are based on objective data of the learning u-curve in the literature, Therefore, this study contributes to the understanding of e-learning temporal patterns, as well as procrastination in e-learning settings, and its implications suggest valuable theoretical and practical insights.

\section{Theoretical Background}

The theoretical background of this study relates to three perspectives, which are intertwined in explaining the rationale of the hypotheses. The first one is temporal learning patterns (Gafni \& Geri, 2010; Spennemann, 2007), and the main concept is procrastination (Steel, 2007). The second aspect is e-learning, and the unique attributes that distinguish it from traditional face-to-face learning (Guri-Rosenblit, 2009). The third perspective pertains to online video lectures and their effectiveness as an informing system (Cohen 1999, 2009; Gill \& Bhatacherjee, 2007, 2009; Gill \& Cohen, 2009).

Procrastination is a well-known, as well as a widely-studied phenomenon, which is the tendency to postpone an activity under one's control to the last possible minute, and sometimes to not perform it at all (Ariely \& Wertenbroch, 2002; Gafni \& Geri, 2010; Steel, 2007; van Eerde, 2003). Chu and Choi (2005) observe that procrastination should not automatically be labeled as a negative phenomenon. Considering our limited attention resources (Davenport \& Beck, 2001), individuals must set their priorities and rationally decide to postpone certain assignments. People who are active procrastinators prefer to work under pressure and make intentional decisions to procrastinate, notwithstanding, they generally manage to complete their tasks on time. On the other hand, passive procrastinators are paralyzed by their indecision and consequently fail to complete their assignments on time.

Since students have limited attention and time resources, they may decide on active procrastination and focus on studying for the exam. Other students might have difficulties in studying the course and become passive procrastinators. Although the reasons for procrastination are very different, their consequences as reflected by temporal learning patterns are similar. Our first hypothesis is that in general, there is a u-curve of e-learning.

H1: General temporal e-learning patterns follow a u-curve, with decreased use in the middle of the semester that increases toward the end, and becomes highest prior the exam.

Online video lectures have become affordable and ubiquitous (Copley, 2007). Previous research reports on successful use of asynchronous online video lectures to support face-to-face learning (Brecht, 2012; Brecht \& Ogilby, 2008; Whatley \& Ahmad, 2007), which actually became a blended learning model. The video option is very helpful for those who cannot attend class (Wieling \& Hofman, 2010), and current technologies offer interactivity, which may improve its 
effectiveness (Zhang, Zhou, Briggs, \& Nunamaker, 2006). However, the flexibility that online video lectures offer students in time, place, and space of learning, has a dark side since they are provided with a comfortable opportunity to procrastinate, which may cause them to fail the course.

While it is expected that students would use course websites the most prior to the exam, it is unclear if they would watch online video lectures during the last days before the exam because watching them is time-consuming. According to cognitive fit theory (Vessey, 1991) compatibility between task and information presentation format is expected to result in superior task performance. Two opposing forces may affect the temporal use patterns of online video lectures. Videos are a time-consuming rich medium of communication (Daft \& Lengel, 1986) that from an attention economy (Shapiro \& Varian, 1999) perspective may be regarded as less efficient than other learning alternatives. Therefore, it might be expected that students would use them less during the last days before the exam. However, if the course is fully online, and is based on those videos, then they may be an essential tool for exam preparation. Moreover, even in blended learning settings, an instructor may prepare a special online video lecture that is intended to help students study for the exam (Brecht \& Ogilby, 2008). Furthermore, procrastinators may delay until the very last days before the exam (Ariely \& Wertenbroch, 2002), and only then attempt to watch the video lectures. This leads us to the next hypothesis regarding online video lecture temporal use patterns.

H2: online video lecture temporal e-learning patterns follow a u-curve, with decreased use in the middle of the semester that increases toward the end, and becomes highest prior the exam.

From a cognitive fit (Vessey, 1991) perspective, there may be differences between pageviews of the homepage, which is intended to help students remain current and informed regarding the course in general, and video, which is time-consuming and requires more effort. However, there is no reason to assume differences between the relative mid-semester decline in homepage views and online video lecture views from the procrastination theatrical angle (Steel, 2007). Since we could not rely on prior research that examined a similar issue, the following hypothesis is exploratory and, therefore, assumes no differences.

H3: There would be no difference between the relative mid-semester decline in homepage views and online video lectures views.

Blended courses and fully online courses are expected to have different temporal use patterns of video. There are several potential reasons why students of fully online courses would relatively view more video during the week before the exam. From the perspective of passive procrastination (Chu \& Choi, 2005), these students might delay viewing the video lectures until just before the deadline (Ariely \& Wertenbroch, 2002), which in this case is the exam day. Another plausible explanation is that in such courses, the video lectures have an important role in conveying the course essentials, so students tend to devote more attention to these videos when preparing for the exam. As we shall further explain in the methodology section, we calculated the ratio of video to homepage views. While according to cognitive fit theory (Vessey, 1991) generally we would expect relative video consumption to decrease, or remain similar to its ratio throughout the semester, in fully online courses that are based on video lectures, we expect the ratio to become higher, as the videos may be a central learning tool in such courses.

H4a: the ratio of video to homepage views would be higher in fully online courses than in blended courses.

$H 4 b$ : In blended courses, the ratio of video to homepage views would decrease prior to the exam. 


\section{H4c: In fully online courses that are based on video lectures, the ratio of video to} homepage views would increase prior to the exam.

Prior research found differences between undergraduate and postgraduate students in procrastination (Cao, 2012; Wang et al., 2013) and their preference for online video lectures, as well as their achievements and retention. Postgraduates are more experienced learners, who have already demonstrated that they have learning abilities and enough perseverance to succeed. Moreover, their previous academic success may decrease their risk of becoming passive procrastinators. This same good experience may make them successful active procrastinators who do not delay too many tasks (Gafni \& Geri, 2010). Therefore, when it comes to time-consuming e-learning activities, like watching video lectures, postgraduates are expected to show less deferment than undergraduates. However, both undergraduates and postgraduates may have similar temporal patterns of viewing the course homepage. This activity keeps the students updated and informed about the course, and it does not necessarily involve actual learning. It may relate to assignment submission dates, updates on learning materials that have been uploaded to the Website, notifications about more or less relevant topics within the course context, and so forth. There is no theoretical justification to assume differences between undergraduates and postgraduates in this regard.

H5a: There would be no difference in the relative mid-semester decline in homepage views between undergraduates and postgraduates.

H5b: There would be a greater relative mid-semester decline in online video lecture views of undergraduates than that of postgraduates.

Steel (2007) observed that task-aversion alone is not enough to predict procrastination, it actually predicts task avoidance. However, combined with other factors, such as the timing of rewards and punishments, it foretells procrastination. Students cannot avoid compulsory courses. Sometimes, they just dislike the subject, other times they may be afraid of failure, or have low self-efficacy (Bandura, 1977, 1997), which is also expected to increase their proclivity to procrastinate. Occasionally, all conditions may occur. A meta-analysis of procrastination (Steel, 2007) indicated that task aversiveness and low self-efficacy are primary reasons for procrastination. In our context, we would expect higher levels of task aversion and low self-efficacy of students enrolled in compulsory courses than of those enrolled in elective ones. This study does not measure these two factors, but rather their consequences, and the literature implies that there would be more evident procrastination in compulsory courses. This is relevant to online video lecture views, which involve learning. However, as mentioned above, it may not hold for homepage views, which may be intended to keep students informed about the course but may not involve active learning. Therefore, we propose the following hypotheses.

\section{H6a: There would be no difference in the relative mid-semester decline in homepage views between compulsory and elective courses. \\ H6b: There would be a greater relative mid-semester decline in online video lecture views of compulsory courses than that of elective courses.}

Steel (2007) proposed that procrastination appears to be growing and urged further investigation. Therefore, we shall examine whether there were changes in procrastination trends over the two year period examined in this study. An increasing trend of procrastination may be explained from an attention economy perspective (Davenport \& Beck, 2001; Geri \& Geri, 2011), as an unfavorable consequence of information overload. However, the pressures of information overload have been evident for several years already, so perhaps they have reached equilibrium in their influence on procrastination. Furthermore, this study is concerned with continued use (Bhattacherjee, 2001; Geri, \& Naor-Elaiza, 2008) patterns, and the examined courses were beyond the stage of online video lecture adoption. The investigated courses included online video lectures for at least 
two years prior to the analyzed period. Therefore, we hypothesize that there would be no difference in the observed procrastination during the period (late 2011 until 2013) examined in this study.

H7a: There would be no differences over time in the general temporal e-learning patterns.

H7b: There would be no differences over time in the online video lecture temporal elearning patterns.

\section{Methodology}

This study used data analytics (LaValle et al., 2011) for analyzing objective data collected by Google Analytics (Clifton, 2012; Pakkala, Presser, \& Christensen, 2012) from the Website of the Open University of Israel that offers its students either distance or blended learning. Several sorts of online video lectures were included in hundreds of the University's course Websites. Students who chose the blended model combined face-to-face class meetings with online support through course websites. These supplemented traditional means of distance education, such as books and study guides.

A course Website usually contained the following components: the homepage, which served as a portal to all the other parts of the website, as well as a bulletin board that the course instructors might use for notifications; discussion boards; supplementary learning materials, such as presentations, sample exams, exercises and solutions; and a main video page that provided access to all the video lectures of the course.

The actual data of students' visits to course Websites was employed to measure temporal use patterns. Two measures were used for each course:

- Pageviews of the course homepage, which represented the general use of the Website.

- Pageviews of the course main video page (if there were two or more entry pages per course all of them were measured, and the aggregated result was used), which represented the use of the online video lectures.

The sample was comprised of 8,977 students, who were enrolled in selected five courses during the years 2012 and 2013. The courses were selected in a manner that would enable exploring other factors that may affect e-learning and online video lecture temporal use patterns. Table 1 presents the five courses and their various categorizations. All the courses were in social sciences.

\section{Table 1: Categorization of the courses}

\begin{tabular}{|l|l|l|l|}
\hline Course & Level & Degree & Format \\
\hline Finance & Compulsory & BA & Mainly blended \\
\hline Information systems & Compulsory & BA & Fully online \\
\hline Political science & Elective & BA & Mainly blended \\
\hline Project management & Elective & MBA & Mainly online \\
\hline Strategy & Elective & MBA & Mainly online \\
\hline
\end{tabular}

Although the university has been using several video technologies, each one of the courses in our sample has been using the same technology of online video lectures for at least two years prior to 
the investigated period, and was taught by the same instructor (different instructors for each one of the courses) during the four examined semesters. Generally, the students were experienced in e-learning. Therefore, the data measured continued use (Bhattacherjee, 2001; Geri, \& NaorElaiza, 2008) patterns of online video lectures. Furthermore, none of the selected courses was considered as introductory, so it was presumed that the students were experienced and had already completed a few courses prior to their inclusion in this study.

In order to measure temporal patterns, each semester was divided into four periods:

- The beginning of the semester, which included its first four weeks. This period was defined according to general observations of aggregate data that relates to all the courses of the university, and it was supported by findings of Michinov et al. (2011).

- The mid-semester.

- The end of the semester, from three weeks prior to the last day of the semester until the day of the last exam, excluding the exam period.

- The exam period, which is defined below.

All the data was standardized as average pageviews per student per week.

There were three alternative dates on which a student might take the exam: two dates immediately following the end of the semester (hereafter, A1 and A2), and one later date (B). Undergraduates might have taken the exam twice, either in A1 or A2, and exam B (or in the following semester). Graduates might have taken the exam only once, either in A1, A2, or B, and the purpose of offering three alternatives was flexibility and convenience. The unique exam period of each course included the combined total of seven days prior to each one of the alternative three dates. The exam day was included as one of the seven days, since the exams always took place in the afternoon. Pageviews per student for the exam period were standardized by the number of students who took the exam in each of these dates.

We evaluated the depth of the mid-semester decline in learning (i.e., the lowest part of the ucurve) by calculating the ratio of pageviews during the mid-semester to the total pageviews. A lower percentage suggests higher procrastination level. The range of the depth was $10 \%-17 \%$ for the homepage, and $10 \%-19 \%$ for the main video page.

\section{Results}

The first two hypotheses, suggesting a u-curve temporal use pattern of e-learning and of online video lectures, were examined by conducting paired-samples t-tests for each of the four periods, together for the five courses, and separately for each one of them. Cohen's d effect sizes were calculated for all the significant results and were found large (over |.96|, meaning less than 50\% overlap). Table 2 provides data on average weekly pageviews per student during the semester, as well as standard deviation for each of the courses alone and for all of them combined. Table 3 presents the paired-samples t-tests results. Figure 1 depicts the u-curve of e-learning. It is evident that for the five courses, for the four examined semesters (2012A, 2012B, 2013A, 2013B) the weighted average pageviews per student per week follow a very similar pattern, with a drop of pageviews during the mid-semester. It is also obvious that the pageviews during the exam period are considerably higher than all the previous periods. 


\begin{tabular}{|c|c|c|c|c|c|c|c|c|}
\hline & Course & & Finance & $\begin{array}{l}\text { Information } \\
\text { systems }\end{array}$ & $\begin{array}{l}\text { Political } \\
\text { science }\end{array}$ & Strategy & $\begin{array}{l}\text { Project } \\
\text { management }\end{array}$ & All \\
\hline n & & & 4 & 4 & 4 & 4 & 4 & 20 \\
\hline \multirow{4}{*}{$\begin{array}{l}\text { Home } \\
\text { page } \\
\text { views }\end{array}$} & 1 - beginning & $\begin{array}{l}\text { Mean } \\
\text { (SD) }\end{array}$ & $\begin{array}{c}5.78 \\
(.79)\end{array}$ & $\begin{array}{l}5.25 \\
(1.05)\end{array}$ & $\begin{array}{l}3.85 \\
(.98)\end{array}$ & $\begin{array}{l}4.89 \\
(1.08)\end{array}$ & $\begin{array}{l}6.22 \\
(1.63)\end{array}$ & \begin{tabular}{|l|}
5.20 \\
$(1.31)$
\end{tabular} \\
\hline & 2 - middle & $\begin{array}{l}\text { Mean } \\
\text { (SD) }\end{array}$ & $\begin{array}{l}3.07 \\
(.32)\end{array}$ & $\begin{array}{l}3.81 \\
(.85)\end{array}$ & $\begin{array}{l}2.40 \\
(.59)\end{array}$ & $\begin{array}{l}3.12 \\
(.34)\end{array}$ & $\begin{array}{l}3.82 \\
(.83)\end{array}$ & $\begin{array}{l}3.25 \\
(.78)\end{array}$ \\
\hline & 3 - end & $\begin{array}{l}\text { Mean } \\
\text { (SD) }\end{array}$ & $\begin{array}{l}5.07 \\
(.33)\end{array}$ & $\begin{array}{l}5.14 \\
(.62)\end{array}$ & $\begin{array}{l}3.22 \\
(.32)\end{array}$ & $\begin{array}{l}4.51 \\
(.48)\end{array}$ & $\begin{array}{l}6.34 \\
(.27)\end{array}$ & $\begin{array}{l}4.86 \\
(1.10)\end{array}$ \\
\hline & Exam & $\begin{array}{l}\text { Mean } \\
\text { (SD) }\end{array}$ & $\begin{array}{l}13.57 \\
(1.82)\end{array}$ & $\begin{array}{l}15.89 \\
(2.17)\end{array}$ & $\begin{array}{l}8.70 \\
(1.37)\end{array}$ & $\begin{array}{l}11.14 \\
(1.52)\end{array}$ & $\begin{array}{l}14.52 \\
(3.54)\end{array}$ & $\begin{array}{l}12.76 \\
(3.28)\end{array}$ \\
\hline \multirow{4}{*}{$\begin{array}{l}\text { Main } \\
\text { video } \\
\text { page } \\
\text { views }\end{array}$} & 1 - beginning & $\begin{array}{l}\text { Mean } \\
\text { (SD) }\end{array}$ & $\begin{array}{l}1.30 \\
(.19)\end{array}$ & $\begin{array}{l}1.64 \\
(.45)\end{array}$ & $\begin{array}{l}.77 \\
(.17)\end{array}$ & \begin{tabular}{|l|}
.88 \\
$(.25)$
\end{tabular} & $\begin{array}{l}1.37 \\
(.24)\end{array}$ & $\begin{array}{l}1.19 \\
(.41)\end{array}$ \\
\hline & 2 - middle & $\begin{array}{l}\text { Mean } \\
\text { (SD) }\end{array}$ & $\begin{array}{l}1.04 \\
(.10)\end{array}$ & $\begin{array}{l}1.23 \\
(.25)\end{array}$ & $\begin{array}{l}.52 \\
(.17)\end{array}$ & \begin{tabular}{|l|}
.51 \\
$(.08)$
\end{tabular} & \begin{tabular}{|l|}
.84 \\
$(.15)$
\end{tabular} & \begin{tabular}{|l}
.83 \\
$(.32)$
\end{tabular} \\
\hline & 3 - end & $\begin{array}{l}\text { Mean } \\
\text { (SD) }\end{array}$ & $\begin{array}{l}2.09 \\
(.44)\end{array}$ & $\begin{array}{l}1.69 \\
(.47)\end{array}$ & $\begin{array}{l}.67 \\
(.14)\end{array}$ & \begin{tabular}{|l}
58 \\
$(.12)$
\end{tabular} & $\begin{array}{l}1.23 \\
(.23)\end{array}$ & $\begin{array}{l}1.25 \\
(.66)\end{array}$ \\
\hline & Exam & $\begin{array}{l}\text { Mean } \\
\text { (SD) }\end{array}$ & $\begin{array}{l}3.81 \\
(.28)\end{array}$ & $\begin{array}{l}6.14 \\
2.21)\end{array}$ & $\begin{array}{l}1.69 \\
(.15)\end{array}$ & $\begin{array}{l}1.48 \\
.26)\end{array}$ & $\begin{array}{l}2.09 \\
.20)\end{array}$ & $\begin{array}{l}3.04 \\
(2.01)\end{array}$ \\
\hline
\end{tabular}

\begin{tabular}{|c|c|c|c|c|c|c|c|}
\hline \multicolumn{8}{|c|}{ Table 3: paired-samples t-tests of temporal patterns } \\
\hline & $\begin{array}{l}\text { Compared } \\
\text { periods }\end{array}$ & Finance & $\begin{array}{l}\text { Information } \\
\text { systems }\end{array}$ & $\begin{array}{l}\text { Political } \\
\text { science }\end{array}$ & Strategy & $\begin{array}{l}\text { Project } \\
\text { management }\end{array}$ & All \\
\hline \multirow{6}{*}{$\begin{array}{l}\text { Home } \\
\text { page } \\
\text { views }\end{array}$} & $1-2$ & 6.554** & $2.499^{*}$ & $4.819 * *$ & $3.47 * *$ & $2.763^{*}$ & $7.684^{* *}$ \\
\hline & $1-3$ & 1.381 & 0.235 & 1.759 & 0.508 & -0.131 & 1.326 \\
\hline & 1-exam & $-7.862^{* *}$ & $-9.59 * *$ & $-10.212 * *$ & $-8.563 * *$ & $-8.598 * *$ & $-13.273 * *$ \\
\hline & $2-3$ & $-6.462^{* *}$ & -1.959 & $-5.385^{* * *}$ & $-4.303 * *$ & $-5.415 * *$ & $-7.47 * *$ \\
\hline & 2-exam & $-10.667^{* * *}$ & $-9.625^{* *}$ & $-9.561^{* *}$ & $-11.416 * *$ & $-6.249 * *$ & $-14.54^{* *}$ \\
\hline & 3-exam & $-10.315 * *$ & $-9.362^{* *}$ & $-8.934 * *$ & $-9.079 * *$ & $-4.460 * *$ & $-13.049 * *$ \\
\hline \multirow{6}{*}{$\begin{array}{l}\text { Main } \\
\text { video } \\
\text { page } \\
\text { views }\end{array}$} & $1-2$ & $2.401^{*}$ & 1.365 & $2.96^{*}$ & $3.986^{* * *}$ & $3.700 * *$ & $5.142 * *$ \\
\hline & $1-3$ & $-2.665^{*}$ & -0.119 & 1.525 & 2.015 & 0.699 & -.442 \\
\hline & 1-exam & $-54.637 * *$ & $-3.608^{*}$ & $-17.228 * *$ & $-2.935^{*}$ & $-4.428 * *$ & $-4.504 * *$ \\
\hline & $2-3$ & $-4.275^{* *}$ & $-2.21 *$ & $-2.672 *$ & -0.75 & $-2.257^{*}$ & $-4.061^{* *}$ \\
\hline & 2-exam & $-19.818^{* * *}$ & $-4.803 * *$ & $-30.427 * *$ & $-7.452 * *$ & $-7.556 * *$ & $-5.674^{* *}$ \\
\hline & 3-exam & $-5.08 * *$ & $-5.026^{* *}$ & $-16.992 * *$ & $-5.385 * *$ & $-6.638 * *$ & $-5.008^{* *}$ \\
\hline
\end{tabular}

** One-tailed significant $\mathrm{p}<.01, *$ One-tailed significant $\mathrm{p}<.05$ 

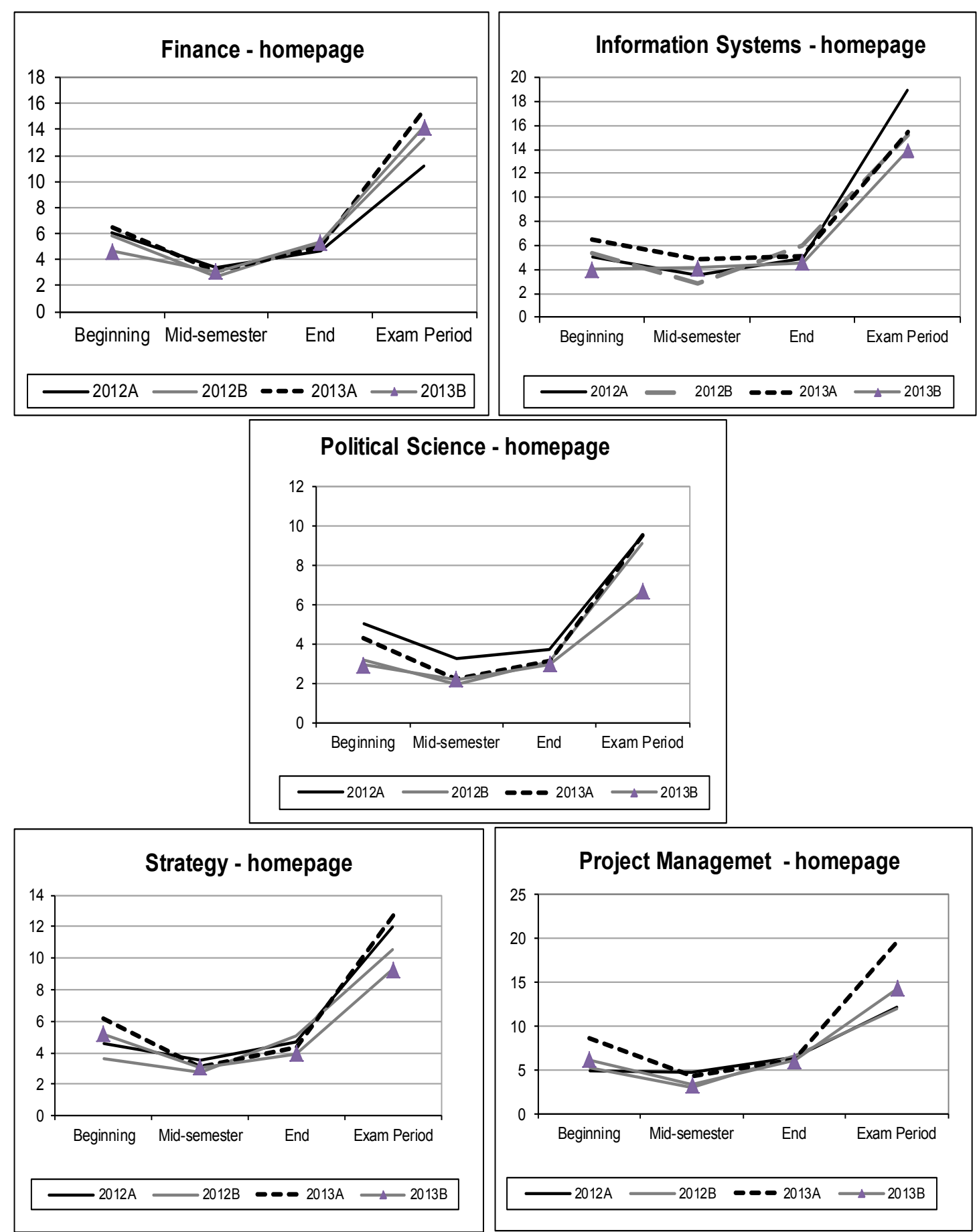

Figure 1: The u-curve of e-learning (weighted average pageviews per student per week)

Figure 2 presents the $\mathrm{u}$-curve of online video lectures and, as can be seen, it is similar to Figure 1 that relates to general e-learning. Both Figures 1 and 2 demonstrate the data in Tables 2 and 3, which shows significant differences between the first period and the middle of the semester for most of the courses, except for one instance; shows a bit less significant results for video pageviews than for homepage views; as expected it shows no significant differences between pe- 
riod 1 and period 3 for all the courses; and finally, a significant difference between the exam period and the others. Thus, $\mathrm{H} 1$ and $\mathrm{H} 2$ were supported.

Table 4 presents the decline during the middle of the semester, and a lower percentage means a deeper decline. As can be seen, there were no significant differences between the relative decline in homepage views and online video lecture views. Hence, H3 was supported.
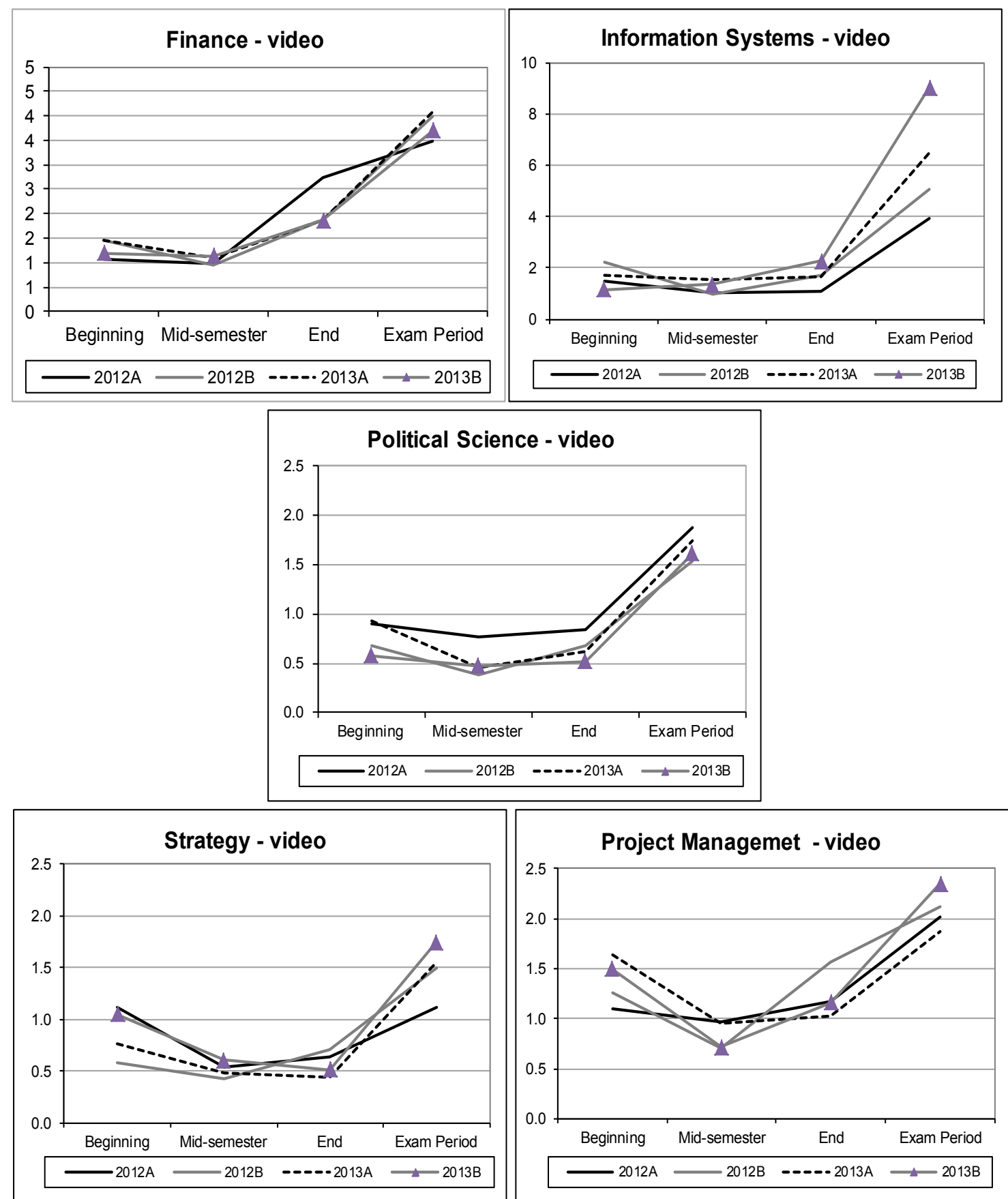

Figure 2: The u-curve of online video lectures (weighted average pageviews per student per week) 


\begin{tabular}{|l|l|l|l|l|l|l|}
\hline \multicolumn{7}{|c|}{ Table 4: Decline in e-learning during the middle of the semester } \\
(\% of pageviews out of total) \\
\hline Page & $\begin{array}{l}\text { Mean } \\
(\mathrm{SD})\end{array}$ & Finance & $\begin{array}{l}\text { Information } \\
\text { systems }\end{array}$ & $\begin{array}{l}\text { Political } \\
\text { science }\end{array}$ & Strategy & $\begin{array}{l}\text { Project } \\
\text { management }\end{array}$ \\
\hline Video & $\begin{array}{l}13.7 \% \\
(.024)\end{array}$ & $12.6 \%$ & $11.7 \%$ & $14 \%$ & $15 \%$ & $15 \%$ \\
\hline Homepage & $\begin{array}{l}12.6 \% \\
(.022)\end{array}$ & $11.0 \%$ & $12.7 \%$ & $13 \%$ & $13 \%$ & $12.5 \%$ \\
& & & & & \\
\hline
\end{tabular}

Table 5 presents the results of a comparison of the fully online course, and all the other courses. As shown, the ratio of video to homepage views is higher in fully online courses, but the differences were not always found significant, due to relatively high variance. We can also see that while the ratio of video use increases in the online course, it decreases in the others, as predicted.

\begin{tabular}{|c|c|c|c|c|}
\hline \multicolumn{5}{|c|}{ Table 5: Relative use of online video lectures } \\
\hline Period & Course type & Mean & SD & t-test (2 tailed) \\
\hline \multirow[t]{2}{*}{ Beginning } & Fully online & $31.4 \%$ & .068 & \multirow{2}{*}{$\begin{array}{l}(\mathrm{t}=4.381, \mathrm{p}=.000,18 \mathrm{df} \text {, equal vari- } \\
\text { ances assumed, Levene's test for equal- } \\
\text { ity of variances: } \mathrm{F}=2.67, \mathrm{p}=.12)\end{array}$} \\
\hline & Others & $20.1 \%$ & .036 & \\
\hline \multirow[t]{2}{*}{ Mid-Semester } & Fully online & $32.3 \%$ & .023 & \multirow{2}{*}{$\begin{array}{l}(\mathrm{t}=2.41, \mathrm{p}=.027,18 \mathrm{df} \text {, equal variances } \\
\text { assumed, Levene's test for equality of } \\
\text { variances: } \mathrm{F}=2.60, \mathrm{p}=.24)\end{array}$} \\
\hline & Others & $23.5 \%$ & .071 & \\
\hline \multirow[t]{2}{*}{ End } & Fully online & $33.4 \%$ & .115 & \multirow[t]{2}{*}{$(\mathrm{t}=.176, \mathrm{NS})$} \\
\hline & Others & $23.6 \%$ & .126 & \\
\hline \multirow[t]{2}{*}{ Exam period } & Fully online & $40.3 \%$ & .186 & \multirow{2}{*}{$\begin{array}{l}(\mathrm{t}=2.222, \mathrm{p}=.107,18 \mathrm{df} \text {, equal vari- } \\
\text { ances not assumed, Levene's test for } \\
\text { equality of variances: } \mathrm{F}=6.43, \mathrm{p}=.021)\end{array}$} \\
\hline & Others & $19.2 \%$ & .067 & \\
\hline
\end{tabular}

No significant difference was found between the mid-semester decline in homepage views between undergraduates (mean $=12.4 \%, \mathrm{SD}=.023$ ) and postgraduates (mean $=12.9 \%, \mathrm{SD}=.021$ ). However, there was a significant difference between the decline in online video lecture pageviews of undergraduates (mean $=12.8 \%, \mathrm{SD}=.022$ ) and graduates (mean $=15.0 \%, \mathrm{SD}=.022$ ), $(\mathrm{t}=-2.248, \mathrm{p}=.037,18 \mathrm{df}$, equal variances assumed, Levene's test for equality of variances: $\mathrm{F}=.17$, $\mathrm{p}=.898$ ). Hence, both H5a and H5b were supported.

No significant difference was found between the mid-semester decline in homepage views between compulsory (mean $=12.0 \%, \mathrm{SD}=.024$ ) and elective courses (mean $=13.0 \%, \mathrm{SD}=.020$ ). As predicted, there was a significant difference between the decline in online video lecture pageviews in compulsory courses (mean $=12.2 \%, \mathrm{SD}=.018$ ) and elective courses (mean $=14.7 \%$, $\mathrm{SD}=.023),(\mathrm{t}=-2.615, \mathrm{p}=.018,18 \mathrm{df}$, equal variances assumed, Levene's test for equality of variances: $\mathrm{F}=.953, \mathrm{p}=.342$ ). Therefore, $\mathrm{H} 6 \mathrm{a}$ and $\mathrm{H} 6 \mathrm{~b}$ were both corroborated by the findings. 
With regard to changes in temporal patterns over the examined period, as evident in Figures 1 and 2 , the patterns were very similar during the whole period, both for the homepage and the video main page pageviews. No significant differences were found, so $\mathrm{H} 7$ was supported.

\section{Discussion}

\section{Theoretical Implications, Limitations and Further Research}

The main theoretical contribution of this study is the definition of a temporal use pattern of course Websites, as the u-curve of e-learning, and defining a similar u-curve for online video lectures, as well as providing empirical objective support for the proposed hypotheses.

When applying the implications of this study its limitations should be considered, and some of them may offer interesting directions for further research. This study was performed at the course level, therefore personal traits of individual students (Wäschle, Allgaier, Lachner, Fink, \& Nückles, 2014) that may affect their temporal e-learning patterns could not be observed. While one of the strengths of this study is its use of a relatively large sample compared to prior research on procrastination (Steel, 2007), and mainly its analysis of objective data, further studies in the individual level, which would be based on varied methodologies (e.g., experiments, surveys), may increase our understanding of e-learning temporal patterns.

The study was conducted in one university, which requires consideration when applying its implications in other settings. However, procrastination is universal, as shown in meta-analyses of prior studies, such as Steel (2007). Furthermore, this study was based on data of 8,977 students, enrolled in five courses, with diverse attributes (compulsory or elective, undergraduate or postgraduate, blended or exclusively fully online, management or political science), over a period of two years. As our findings indicate, all the five courses demonstrated similar temporal patterns, which support their general applicability. Moreover, the study provided empirical evidence for deviations, such as the increased ratio of video to homepage views in fully online courses that are based on video lectures. Nevertheless, since this study is pioneering and one of the first of its kind, further research is required to corroborate the findings.

\section{Practical Implications}

The objective measurement of temporal use patterns of Websites, and their particular components, may help instructional design experts, as well as educators, design courses in a manner that would decrease procrastination and increase student engagement. Although students perceive video lectures as helpful (Steimberg et al., 2010), the availability of video lectures on the course Website may have some negative consequences, such as skipping face-to-face sessions, procrastinating learning until the end of the semester, and eventually failing or dropping-out due to being unable to learn the necessary course materials during the few days before the exam (Geri, 2012). Therefore, we suggest two practical directions that may improve the effectiveness of online video lectures. The first one, which relates directly to the findings of this study, as well as previous ones (Gafni \& Geri, 2010), is to add compulsory assignments throughout the semester that would require learning before the exam. The second direction, which was not examined in this study, but was found effective by others (Cherrett, Wills, Price, Maynard, \& Dror, 2009; Dror, Schmidt, \& O'connor, 2011), is to add interactivity to the videos, in order to improve student engagement. Both of these proposals require further studying.

Furthermore, this study suggested a measure of procrastination, as reflected in the decline in Website visits during the middle of the semester. Hence, instructors and planners would be able to use that measure to identify a need to intervene and take action that may prevent student attri- 
tion, as well as to evaluate if changes they implement increase video lecture watching throughout the semester and decrease procrastination.

\section{Conclusion}

E-learning is a powerful means for increasing learning opportunities and knowledge dissemination and is increasingly gaining popularity in formal higher education, as well as open life-longlearning initiatives, such as MOOCS. However, the ubiquitous availability of e-learning has some unfavorable consequences. This study focused on procrastination, which is partly caused by this prevalent availability of e-learning. The study applied novel data analytics concepts to objectively investigate temporal patterns of course Website use. It identified a quantitative representation of procrastination, presented it visually, as a u-curve, and empirically supported the suggested model by analyzing pageview data of 8,977 students. The study offered a measurement to evaluate procrastination over time, or while comparing different situations, or categories of courses, such as undergraduates versus postgraduates, compulsory versus elective, and so forth. The suggested innovative practical way to measure procrastination may provide practitioners with insights that may help them improve the effectiveness of e-learning.

\section{Acknowledgements}

The authors gratefully acknowledge that this research was supported by a grant from the Israel Internet Association [ISOC-IL].

\section{References}

Ackerman, D., \& Gross, B. L. (2005). My instructor made me do it: Task characteristics of procrastination. Journal of Marketing Education, 27(5), 5-13.

Adipat, B., Zhang, D., \& Zhou, L. (2011). The effects of tree-view based presentation adaptation on mobile web browsing. MIS Quarterly, 35(1), 99-122.

Ariely, D., \& Wertenbroch, K. (2002). Procrastination, deadlines, and performance: Self-control by precommitment. Psychological Science, 13(3), 219-224.

Bandura, A. (1977). Self-efficacy: Toward a unifying theory of behavioral change. Psychological Review, 84(2), 191-215.

Bandura, A. (1997). Self-efficacy: The exercise of control. New York: Freeman.

Bhattacherjee, A. (2001). Understanding information systems continuance: An expectation-confirmation model. MIS Quarterly, 25(3), 351-370.

Brecht, H. D. (2012). Learning from online video lectures. Journal of Information Technology Education, 11, 227-250. Retrieved from http://informingscience.org/jite/documents/Vol11/JITEv11IIPp227250Brecht1091.pdf

Brecht, H. D., \& Ogilby, S. M. (2008). Enabling a comprehensive teaching strategy: Video lectures. Journal of Information Technology Education, 7, 71-86. Retrieved from http://jite.org/documents/Vol7/JITEV7IIP071-086Brecht371.pdf

Cao, L. (2012). Differences in procrastination and motivation between undergraduate and graduate students. Journal of the Scholarship of Teaching and Learning, 12(2), 39-64.

Cherrett, T., Wills, G., Price, J., Maynard, S., \& Dror, I. E. (2009). Making training more cognitively effective: Making videos interactive. British Journal of Educational Technology, 40(6), 1124-1134.

doi: $10.1111 / \mathrm{j} .1467-8535.2009 .00985 . \mathrm{x}$

Chu, A. H., \& Choi, J. N. (2005). Rethinking procrastination: Positive effects of active procrastination on attitudes and performance. Journal of Social Psychology, 145(3), 245-264. 
Clifton, B. (2012). Advanced web metrics with Google Analytics. Indianapolis: Wiley Publishing Inc.

Cohen, E. (1999). Reconceptualizing information systems as a field of the transdiscipline informing science: From ugly duckling to swan. Journal of Computing and Information Technology, 7(3), 213-219.

Cohen, E. (2009). A philosophy of informing science. Informing Science, 12, 1-15. Retrieved from http://inform.nu/Articles/Vol12/ISJv12p001-015Cohen399.pdf

Copley, J. (2007). Audio and video podcasts of lectures for campus-based students: Production and evaluation of student use. Innovations in Education and Teaching International, 44(4), 387-399. doi:10.1080/14703290701602805

Daft, R. L., \& Lengel, R. H. (1986). Organizational information requirements, media richness and structural design. Management science, 32(5), 554-571.

Davenport, T. H., \& Beck, J. C. (2001). The attention economy: Understanding the new currency of business. Boston, MA: Harvard Business School Press.

Dror, I., Schmidt, P. \& O'connor, L. (2011). A cognitive perspective on technology enhanced learning in medical training: Great opportunities, pitfalls and challenges. Medical Teacher, 33(4), 291-296. doi:10.3109/0142159X.2011.550970

Gafni, R., \& Geri, N. (2010). Time management: Procrastination tendency in individual and collaborative tasks. Interdisciplinary Journal of Information, Knowledge, and Management, 5, 115-125. Retrieved from http://www.ijikm.org/Volume5/IJIKMv5p115-125Gafni448.pdf

Geri, N. (2012). The resonance factor: Probing the impact of video on student retention in distance learning. Interdisciplinary Journal of E-Learning and Learning Objects, 8, 1-13. Retrieved from http://www.ijello.org/Volume8/IJELLOv8p001-013Geri0794.pdf

Geri, N., \& Geri, Y. (2011). The information age measurement paradox: Collecting too much data. Informing Science, 14, 47-59. Retrieved from http://www.inform.nu/Articles/Vol14/ISJv14p047059Geri587.pdf

Geri, N., \& Naor-Elaiza, O. (2008). Beyond adoption: Barriers to an online assignment submission system continued use. Interdisciplinary Journal of E-Learning and Learning Objects, 4, 225-241. Retrieved from http://ijello.org/Volume4/IJELLOv4p225-241Ger476.pdf

Gill, T. G., \& Bhatacherjee, A. (2007). The informing sciences at a crossroads: The role of the client. Informing Science, 10, 17-39. Retrieved from http://inform.nu/Articles/Vol10/ISJv10p017039Gill317.pdf

Gill, T. G., \& Bhattacherjee, A. (2009). Whom are we informing? Issues and recommendations for MIS research from an informing science perspective. MIS Quarterly, 33(2), 217-235.

Gill, T. G., \& Cohen, E. (Eds.). (2009). Foundations of informing science, 1999-2008. Santa Rosa, CA: Informing Sciences Press.

Grinberg, N., Naaman, M., Shaw, B., \& Lotan, G. (2013). Extracting diurnal patterns of real world activity from social media. Proceedings of the 7th International AAAI Conference on Weblogs and Social Media (ICWSM), July 8-10, 2013, Boston. Retrieved from http://sm.rutgers.edu/pubs/GrinbergSMPatterns-ICWSM2013.pdf

Guri-Rosenblit, S. (2009). Digital technologies in higher education: Sweeping expectations and actual effects. New York, NY: Nova Science Publishers.

Hershkovitz, A. \& Nachmias, R. (2009). Learning about online learning processes and students' motivation through Web usage mining. Interdisciplinary Journal of E-Learning and Learning Objects, 5, 197-214. Retrieved from http://ijklo.org/Volume5/IJELLOv5p197-214Hershkovitz670.pdf

Kachgal, M., Hansen, L. S., \& Nutter, K. J.(2001). Academic procrastination prevention/intervention strategies and recommendations. Journal of Developmental Education, 25 (Fall), 14-24. 
LaValle, S., Lesser, E., Shockley, R., Hopkins, M. S., \& Kruschwitz, N. (2011). Big data, analytics and the path from insights to value. MIT Sloan Management Review, 52(2), 21-32.

Levy, Y., \& Ramim, M. M. (2012). A study of online exams procrastination using data analytics techniques. Interdisciplinary Journal of E-Learning and Learning Objects, 8, 97-113. Retrieved from http://www.ijello.org/Volume8/IJELLOv8p097-113Levy0804.pdf

Michinov, N., Brunot, S., Le Bohec, O., Juhel, J., \& Delaval, M. (2011). Procrastination, participation, and performance in online learning environments. Computers \& Education, 56(1), 243-252.

Moore, M., \& Kearsley, G. (2011). Distance education: A systems view of online learning (3rd ed.). Belmont, CA: Wadsworth Publishing.

Özer, B. U., Demir, A., \& Ferrari, J. R. (2009). Exploring academic procrastination among Turkish students: Possible gender differences in prevalence and reasons. The Journal of Social Psychology, 149(2), 241-257.

Pakkala, H., Presser, K., \& Christensen, T. (2012). Using Google Analytics to measure visitor statistics: The case of food composition Websites. International Journal of Information Management, 32(6), 504-512.

Rakes, G. C., \& Dunn, K. E. (2010). The impact of online graduate students' motivation and self-regulation on academic procrastination. Journal of Interactive Online Learning, 9(1), 78-93.

Shapiro, C. \& Varian, H. R. (1999). Information rules. A strategic guide to the network economy. Boston, Massachusetts: Harvard Business School Press.

Spennemann, D. H. R. (2007). Learning and teaching 24/7: Daily Internet usage patterns at nine Australian universities. Campus-Wide Information Systems, 24(1), 27-44.

Steel, P. (2007). The nature of procrastination: A meta-analytic and theoretical review of quintessential self-regulatory failure. Psychological Bulletin, 133(1), 65-94. DOI: 10.1037/0033-2909.133.1.65

Steimberg, Y., Guterman, E., Mermelstein, B., Brickner, R., Alberton, Y., \& Sagi, R. (2010). Students' perspective on teaching and learning with video technology at the Open University of Israel. In Y. Eshet-Alkalai, A. Caspi, S. Eden, N. Geri, \& Y. Yair (Eds.), Learning in the Technological Era: Proceedings of the Chais Conference on Instructional Technologies research (pp. 186H-194H). Raanana, Israel: The Open University of Israel. [in Hebrew] Retrieved from http://telem-pub.openu.ac.il/users/chais/2010/after_noon/4_1.pdf

van Eerde, W. (2003). Procrastination at work and time management training. Journal of Psychology, 137, 421-434.

Vessey, I. (1991). Cognitive fit: A theory-based analysis of the graphs versus tables literature. Decision Sciences, 22(2), 219-240.

Wang, N., He, P., \& Li, Q. (2013). The relationship between postgraduates' academic procrastination and psychodynamic variables. Proceedings of International Conference on Education, Management and Social Science (ICEMSS 2013) (pp. 54-57). Atlantis Press.

Wäschle, K., Allgaier, A., Lachner, A., Fink, S., \& Nückles, M. (2014). Procrastination and self-efficacy: Tracing vicious and virtuous circles in self-regulated learning. Learning and Instruction, 29, 103-114. DOI: 10.1016/j.learninstruc.2013.09.005

Whatley, J., \& Ahmad, A. (2007). Using video to record summary lectures to aid students' revision. Interdisciplinary Journal of Knowledge and Learning Objects, 3, 185-196. Retrieved from http://ijklo.org/Volume3/IJKLOv3p185-196Whatley367.pdf

Wieling, M. B., \& Hofman, W. H. A. (2010). The impact of online video lecture recordings and automated feedback on student performance. Computers \& Education, 54 (4), 992-998.

Zhang, D., Zhou, L., Briggs, R. O., \& Nunamaker, J. F. Jr. (2006). Instructional video in e-learning: Assessing the impact of interactive video on learning effectiveness. Information \& Management, 43 (1), $15-27$. 


\section{Biographies}

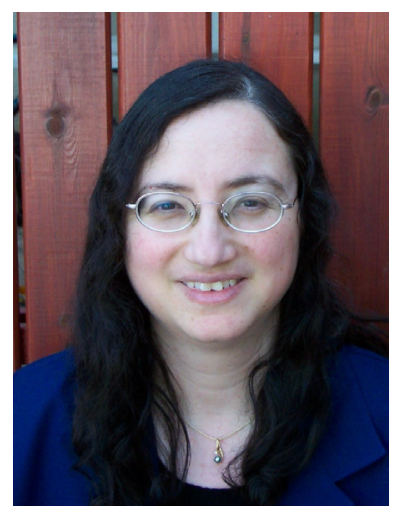

Nitza Geri is a faculty member at the Open University of Israel, Department of Management and Economics, and Head of the Research Center for Innovation in Learning Technologies. She holds a B.A. in Accounting and Economics, an M.Sc. in Management Sciences and a $\mathrm{Ph} . \mathrm{D}$. in Technology and Information Systems Management from TelAviv University. Nitza is a CPA (Israel) and prior to her academic career she had over 12 years of business experience. Her research interests and publications focus on various aspects of the value of information, and information systems adoption and implementation, including strategic information systems, e-business, economics of information goods, attention economy, knowledge management, value creation and the Theory of Constraints, managerial aspects of e-learning systems adoption and use. Personal site: http://www.openu.ac.il/Personal_sites/nitza-geri.html

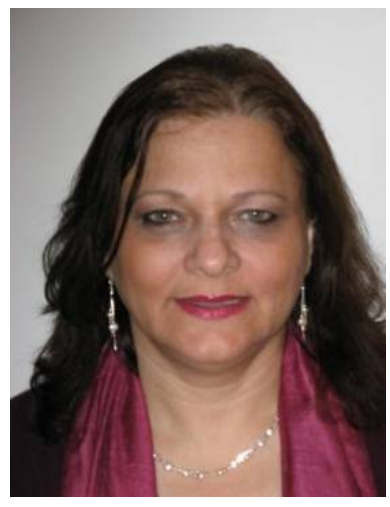

Ruti Gafni holds a PhD from Bar-Ilan University, Israel (in the Business Administration School), focusing in Information Systems. She also holds an M.Sc. from Tel Aviv University and a BA (Cum Laude) in Economics and Computer Science from Bar-Ilan University. She has more than 30 years of practical experience as Project Manager and Analyst of information systems. She is the Head of the Management of Information Systems BA program at The Academic College of Tel Aviv Yaffo. She also teaches in the Management and Economics MBA program at the Open University of Israel.

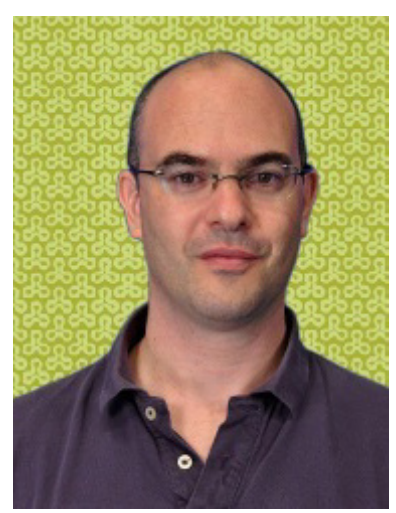

Amir Winer Heads the Interactive Courseware unit and the Digital Textbooks Initiative at the Open University of Israel. He served as a special digitation consultant for Israel's Ministry of Education and led the design of Israel's standard for developing K12 Digital Textbooks. Prior to joining the Open University of Israel, Amir was Head of R\&D at the Center for Futurism in Education at Ben Gurion University. Amir holds an MA in Psychology and a BA in Cognitive Science, both from Ben-Gurion University. 